\title{
EFFECT OF ENVIRONMENTAL POLLUTION WITH TETRACYCLINE AND CADMIUM ON CHLOROPHYLL CONTENT IN SPINACH (SPINACIA OLERACEA L.) LEAVES SUBJECTED TO COLD STORAGE
}

\author{
RYDZYŃSKI, D. ${ }^{1,2}$ - PIOTROWICZ-CIEŚLAK, A. I. ${ }^{1 *}$ - GRAJEK, H. $^{2}$ - BOROWSKA, E. J. ${ }^{3}$ \\ ${ }^{I}$ Department of Plant Physiology, Genetics and Biotechnology, Faculty of Biology and \\ Biotechnology, University of Warmia and Mazury in Olsztyn, Oczapowskiego 1A, 10-718 \\ Olsztyn, Poland \\ ${ }^{2}$ Department of Physics and Biophysics, Faculty of Food Science, University of Warmia and \\ Mazury in Olsztyn, Oczapowskiego 4, 10-719 Olsztyn, Poland \\ ${ }^{3}$ Department of Food Plant Chemistry and Processing, Faculty of Food Science, University of \\ Warmia and Mazury in Olsztyn, Plac Cieszyński 1, 10-957 Olsztyn, Poland \\ *Corresponding author \\ e-mail:acieslak@uwm.edu.pl \\ (Received $11^{\text {th }}$ Feb 2019; accepted $8^{\text {th }}$ Apr 2019)
}

\begin{abstract}
This paper analysed chlorophyll degradation in spinach leaves from plants affected by cadmium and tetracycline soil contamination, stored for 32 weeks at $\mathrm{t}=-18^{\circ} \mathrm{C}$. The first-order reaction kinetics were determined for chlorophyll degradation. In plants growing on soil containing tetracycline and cadmium, two ranges of chlorophyll degradation occur: 1 - a slow degradation, during storage for up to 20 weeks, occurring at constant degradation rate, $k=0.00594 \pm 0.00029$ week $^{-1}$ for tetracycline and $k=0.00761 \pm 0.00026$ week $^{-1}$ for cadmium, and $2-$ a fast degradation, occurring later, with constant $k=0.04484 \pm 0.00137$ week $^{-1}$ and $k=0.06777 \pm 0.00171$ week $^{-1}$ for tetracycline and cadmium, respectively. Those two ranges were not observed for spinach growing without contamination $\left(\mathrm{k}=0.00679 \pm 0.00027\right.$ week $\left.^{-1}\right)$. Chlorophyll degradation occurred eight times faster for tetracycline and ten times faster for cadmium. After 32 weeks of storage $19.4 \%$ and $13.6 \%$ of chlorophyll were left in small leaves affected by tetracycline and cadmium, respectively. In spinach leaves of harvesting maturity (50-days-old, large leaves), lower values of rate constants were found for range 2, amounting for dose $\left(90 \mathrm{mg} / \mathrm{kg}\right.$ soil) to $k=0.02945 \pm 0.00151$ week $^{-1}$ (for tetracycline) and $\mathrm{k}=0.03511 \pm 0.00124$ week $^{-1}$ (for cadmium) and 50\% chlorophyll was left after 32 weeks. Chlorophyll degradation degree depends on soil contamination, leaf size and time of exposure to contaminants.
\end{abstract}

Keywords: chlorophyll content, chlorophyll degradation, absorption and fluorescence spectra, degradation rate, storage of spinach

\section{Introduction}

The spinach is a popular vegetable due to its taste and sensory values. Spinach leaf chemical composition is also significant, including the high level of vitamin $(\mathrm{C}, \mathrm{E})$, folic acid, polyphenols, $\beta$-carotene, mineral component and dietary fibre, as well as strong antioxidant properties related to the high chlorophyll content (Jaworska, 2005; Lisiewska et al., 2009; Xie et al., 2013). A drawback of spinach is its short shelf life in a chilled state. After being subject to minimum processing, spinach packed in perforated bags remains fit for consumption for eight days when stored in the refrigerator at $8{ }^{\circ} \mathrm{C}$ (Kou et al., 2014). For this reason, spinach leaves are very often purchased by consumers in a frozen form (Jaworska and Kmiecik, 2000). Freezing is one of the most 
frequently applied food storage methods. Despite undeniable usefulness of spinach storage at freezing temperatures, such treatments also have negative effects on food quality. Freezing involves physical changes, such as re-crystallization of ice and moisture migration, resulting in a decrease in weight and nutrient content, as well as changes in the product texture (Van Buggenhout et al., 2006; Pukszta and Palich, 2007). In the freezing process, chemical changes also take place, which can result in a change in taste or colour (Lisiewska et al., 2009). The colour is of great importance, since it is one of main factors considered by consumers purchasing fruit and vegetables. Orange and yellow colour of vegetables is, to a significant extent, caused by carotenoids, while green is related to the presence of chlorophyll (Sánchez et al., 2014). The change of the green colour in frozen products is related to degradation of chlorophyll content in plants (Koca et al., 2007). Chlorophyll degradation occurs not only when leaves are being frozen, but also in plants growing in a contaminated environment (Bartha et al., 2010; Kong et al., 2007). The main environmental contaminants include heavy metals and antibiotics, which have also been emphasized recently as cropland contaminating factors (Zhang et al., 2016). Progressive contamination results in increasing the content of antibiotics and heavy metals in soils and surface water (Azeez et al., 2009; Kim and Carlson, 2007; Nicholson et al., 2003). Contamination of arable soils in Poland with cadmium exceeded $90.87 \mathrm{mg} / \mathrm{kg}$ in 2000 (IUNG, 2017). Both heavy metals and antibiotics are taken up by plants from soil (Pan and Chu, 2017). After taking up, they are transported to the above-ground parts, including leaves, where they disturb the process of photosynthesis. The plant's response to environmental contamination caused by heavy metals has been quite well explored. It is known that heavy metals replace a magnesium atom in chlorophyll, creating chlorophyll-metal bonds (Küpper et al., 2000, 2001). Chlorophyll and metal complexes, even if they occur in low amounts in relation to pure chlorophyll, can entirely inhibit the process of photosynthesis (Küpper et al., 1996). Metals with high toxicity towards plants include cadmium (Smeets et al., 2005; Mishra et al., 2006), this toxicity mainly results from changes occurring in the process of photosynthesis and changes in the structure and the content of photosynthetic dyes (Kummerova et al., 2006; López-Millán et al., 2009). Just like heavy metals, antibiotics also reduce the chlorophyll content in plants, thus reducing the process of photosynthesis (D'Abrosca et al., 2008; Li et al., 2011; Liu et al., 2013).

The effect of plant contamination with heavy metals or antibiotics on chlorophyll concentration in leaves intended for freezing has not yet been examined. The aim of this study was to determine changes in chlorophyll concentration during the storage of spinach containing cadmium and tetracycline. Additionally, the contents of tetracycline and cadmium, as soil pollutants, were analysed for any effect on the quality of frozen raw material.

\section{Material and methods}

\section{Materials}

The research material consisted of spinach (Spinacia oleracea L.) plants, Matador cultivar. The seeds were sown to the soil in $300 \mathrm{ml}$ pots. After 20 or 40 days of plant growth, aqueous solutions of cadmium sulphate $(\mathrm{Cd})$ and tetracycline (TC) at concentrations of 3,45 and $90 \mathrm{mg} / \mathrm{kg}$ soil were added to the pots. Due to the fact that soil pollution in Poland exceeds $90 \mathrm{mg} / \mathrm{kg}$ of cadmium, the same concentrations for cadmium and tetracycline were used for comparison. Additionally, we applied to 


$$
-6823-
$$

smaller doses for large leaves -3 and $45 \mathrm{mg} / \mathrm{kg}$. After ten days as of adding metal and antibiotics to the soil, the leaves were cut, washed with water and prepared for freezing.

The spinach was frozen in two variants:

1. Small leaves (SL) - with a surface area of $10 \pm 0.5 \mathrm{~cm}^{2}$, growing for 30 days, of which 10 days on the soil containing TC and $\mathrm{Cd}$ in the dose of $90 \mathrm{mg} / \mathrm{kg}$ soil.

2. Large leaves (BL) - with a surface area of $55 \pm 2 \mathrm{~cm}^{2}$, growing for 50 days (harvesting maturity of leaves) of which 10 days on the soil containing with TC and $\mathrm{Cd}$ in the dose of 3,45 and $90 \mathrm{mg} \mathrm{kg}$ soil.

$\mathrm{BL}$ and SL leaves were homogenized and stored in the freezer at $-18{ }^{\circ} \mathrm{C}$ for 32 weeks. The temperature was additionally monitored with a thermometer located in the freezer. Samples from the freezer were collected at one week intervals. Analyses were performed in five replications. Leaves from plants growing on soil not contaminated with cadmium or tetracycline were used as control. The leaves were stored in parallel with the plant material from contaminated soil.

\section{Chlorophyll extraction}

Chlorophyll was extracted from spinach leaves $(300 \mathrm{mg})$ with $5 \mathrm{ml}$ of methanol (Rydzyński et al., 2017). The obtained homogenate was centrifuged at room temperature at 4,000 RPM. The extract was then 5-fold diluted and used for spectrophotometric and fluorometric analyses. All extraction procedures were conducted in cold temperatures and dim light.

\section{Absorption and fluorescence spectra}

The absorption and fluorescence spectra of solutions were measured using, respectively, the Carry 5000 UV-Visible Spectrophotometer (Varian, Inc) and a Cary Eclipse Fluorescence Spectrophotometer (Varian, Inc) with right-angle geometry. The fluorescence spectra were measured at excitation wavelength $\lambda_{\text {exc }}=650 \mathrm{~nm}$. Chlorophyll concentrations were calculated, based on Lambert-Beer law, on the basis of the known molar extinction coefficient of chlorophyll in methanol, which is $\varepsilon=66600 \mathrm{M}^{-1} \mathrm{~cm}^{-1}$ in the first chlorophyll absorption band maximum (Seely and Jensen, 1965).

\section{Results and discussion}

Chlorophyll is not only an indispensable plant dye, but has also been proven to be an important compound for the human body, with favourable antihyperglycemic and antihyperlipidemic properties (Patar et al., 2016). Chlorophyll also demonstrates antioxidant effects, eliminates free radicals and shows a positive effect in cancer treatment (Gore et al., 2017). Therefore, reduction of the chlorophyll content in the human diet is highly undesirable.

It was proven (Rydzyński et al., 2017) that plants growing on soils contaminated with antibiotics feature a high decrease in chlorophyll. Therefore, the consumption quality of plants growing on such soils is impaired. The present study examined the process of chlorophyll degradation in plants growing on soil contaminated with antibiotics and heavy metal (cadmium), during the storage of such leaves at $\mathrm{t}=-18{ }^{\circ} \mathrm{C}$ for 32 weeks. 
Figure $1 A$ and $A$ ' present changes in the absorption and fluorescence spectra of chlorophyll extracted from spinach grown on soil without (control) the content of tetracycline or cadmium and stored at $\mathrm{t}=-18^{\circ} \mathrm{C}$ for 32 weeks. During the storage, absorption decreased from $\mathrm{A}_{1}=1.122$ to $\mathrm{A}_{32}=0.874$. Chlorophyll concentration was reduced from the value of $\mathrm{C}_{0}=8.42 \times 10^{-5} \mathrm{M}$ to $\mathrm{C}_{32}=6.56 \times 10^{-5} \mathrm{M}$. Chlorophyll concentration decreased by $22 \%$, which is in agreement with the results obtained by Dermesonluoglu et al. (2015) in the storage of frozen spinach at $-18{ }^{\circ} \mathrm{C}$.
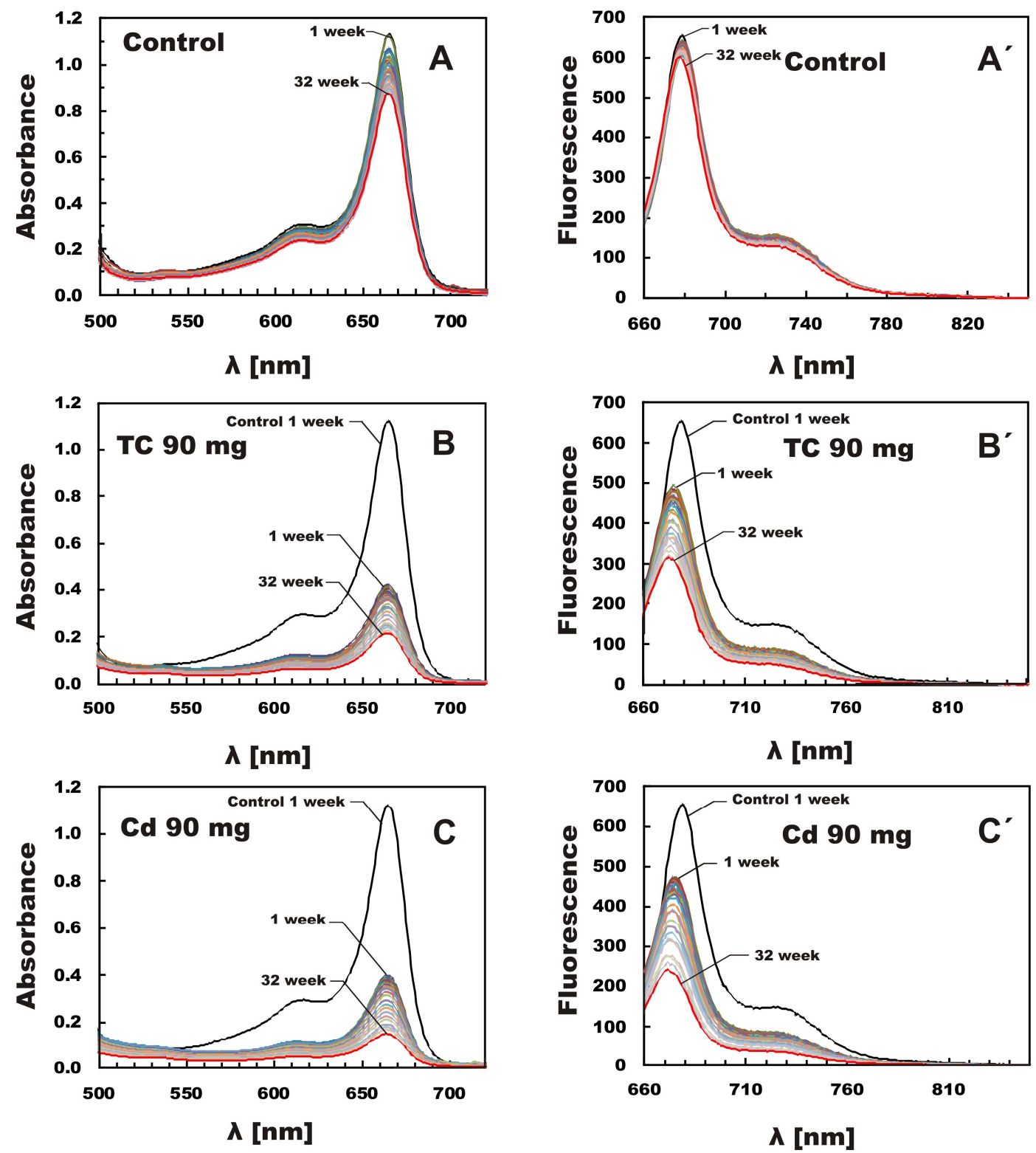

Figure 1. Absorption ( $A, B, C)$ and fluorescence $\left(A^{\prime}, B^{\prime}, C^{\prime}\right)$ spectra for chlorophyll extracted from stored (small) spinach leaves growing on soil: $A, A$ ' - without contamination (contol); $B$, $B^{\prime}$ - containing $90 \mathrm{mg}$ tetracycline (TC); C, C' - containing $90 \mathrm{mg}$ cadmium (Cd) per $\mathrm{kg}$ soil

Figure 1B, $B$ ', $C$ and $C^{\prime}$ present, respectively, the absorption and fluorescence spectra of chlorophyll obtained from spinach plants growing on soil containing TC and 
$\mathrm{Cd}$, and stored at $\mathrm{t}=-18^{\circ} \mathrm{C}$ for 32 weeks. In these figures, the chlorophyll absorption and fluorescence spectrum for spinach without TC and $\mathrm{Cd}$ treatment (control) was added.

As Figure $1 B$ shows, the absorption of chlorophyll extracted from plant leaves growing for 10 days in soil containing TC $(90 \mathrm{mg} / \mathrm{kg})$ decreased by $64 \%$ in relation to the control sample (from the value of $\mathrm{A}=1.12$ to $\mathrm{A}=0.407$ ) and Figure $1 \mathrm{C}$ demonstrates that for cadmium treatment $(90 \mathrm{mg} / \mathrm{kg})$, a decrease of $65 \%$ was observed (to the value of $\mathrm{A}=0.394$ ). The decrease observed occurred in leaves growing on contaminated soil, even before spinach leaves underwent the freezing process. The leaves growing on soil contaminated with $\mathrm{TC}$ and $\mathrm{Cd}$, containing less chlorophyll, were then subject to the freezing process, as a result of which, as can be seen in Figure $1 B$ and $C$, a further decrease in chlorophyll took place: absorption was reduced from $\mathrm{A}_{1}=0.407$ to $\mathrm{A}_{32}=0.217$ (a further decrease in chlorophyll concentration to the value of $\mathrm{C}_{32}=1.63 \times 10^{-5} \mathrm{M}$ ) for $\mathrm{TC}$, and to the value of $\mathrm{A}_{32}=0.152$ (a decrease in concentration to the value of $\mathrm{C}_{32}=1.14 \times 10^{-5} \mathrm{M}$ ) for $\mathrm{Cd}$. After 32 weeks of storage, $19.4 \%$ chlorophyll content remained in $\mathrm{TC}$ contaminated leaves and $13.6 \%$ in $\mathrm{Cd}$ contaminated leaves.

It can be clearly seen that during the low temperature storage of spinach leaves grown on soil contaminated with $\mathrm{TC}$ and $\mathrm{Cd}$, a further process of chlorophyll degradation took place. In the fluorescence spectra (Fig. 1B' and $C^{\prime}$ ) major changes are observed - a large decrease in fluorescence concentration, particularly for samples containing cadmium. The fluorescence spectrum clearly shifted towards shorter wavelengths by $6 \mathrm{~nm}$ at TC contamination, and by $8 \mathrm{~nm}$ at Cd contamination, which clearly proves the formation of chlorophyll degradation products. A high decrease in absorbance between the control sample and the first week of freezing for spinach containing TC or Cd results from chlorophyll degradation in the plant under the effect of tetracycline and cadmium, while a further decrease in chlorophyll content was caused by the storage process.

Figure 2 presents the relation between chlorophyll concentration in spinach leaves (SL) and the time of storage at $\mathrm{t}=-18{ }^{\circ} \mathrm{C}$. These figures present the values of chlorophyll concentration for five independent samples of spinach leaves in the function of storage time. Statistical data of these changes is shown in Table Al in the Appendix. For spinach grown on soil contaminated with antibiotic and metal, two ranges of chlorophyll degradation can be distinguished: the first range of slow degradation up to week 20, and the second range, of the so-called faster degradation. King et al. (2001) also observed a two-range course of chlorophyll degradation rate, but during dehydration by freeze-drying at $-5^{\circ} \mathrm{C},-20{ }^{\circ} \mathrm{C},-30{ }^{\circ} \mathrm{C}$ and $45^{\circ} \mathrm{C}$. At the beginning, for 6 days of the process, they observed fast Chl degradation, followed by slow degradation. Those two ranges were recorded for blanched spinach, particularly at $-5{ }^{\circ} \mathrm{C}$ and $-30{ }^{\circ} \mathrm{C}$. In the current study, two ranges of chlorophyll degradation were not observed for spinach growing on uncontaminated soil (control).

On the basis of concentrations obtained, the kinetics of chlorophyll degradation during spinach storage time was examined. As provided in the literature (Koca et al., 2007; Dermesonluoglu et al., 2015; Steet and Tong, 1996) in the examined cases, total chlorophyll loss in vegetables during various technological processes was described by $1^{\text {st }}$ order reaction kinetics.

The concentration of chlorophyll as a function of time at a constant temperature for a first-order degradation kinetics model is: 


$$
c=c_{0} e^{-k t}
$$

where $\mathrm{C}$ is the chlorophyll concentration at any time $\mathrm{t}, \mathrm{C}_{\mathrm{o}}$ is the initial concentration, and $k$ is the first-order constant estimated by slope of the linearized plot of $\operatorname{lnC}$ vs $t$.

Chlorophyll degradation reactions during spinach storage for 32 weeks at low temperature $\mathrm{t}=-18^{\circ} \mathrm{C}$ were described by 1 st order kinetics (Fig. 3). The $\operatorname{lnC}$ function linearly described the dependence of chlorophyll concentration decrease in the time of leaf storage at $\mathrm{t}=-18^{\circ} \mathrm{C}$ in both ranges for contaminated spinach, and in one range for uncontaminated spinach.
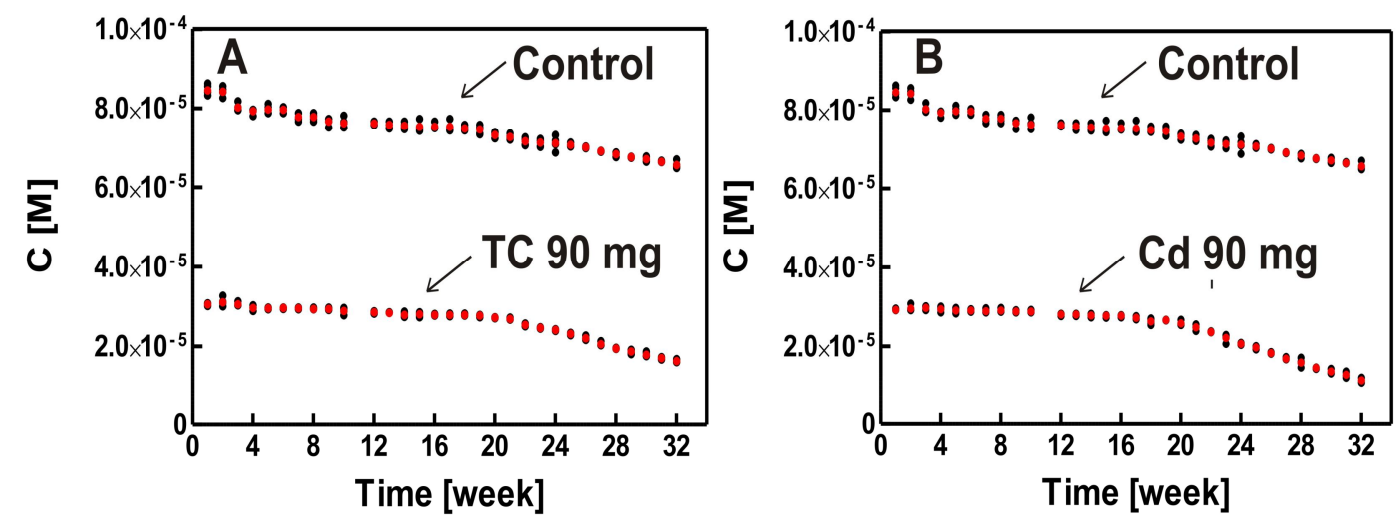

Figure 2. Relation between chlorophyll concentration (C[M]) in small spinach leaves and storage time. A - plants growing with TC (90 mg/kg soil), B - with $\mathrm{Cd}(90 \mathrm{mg} / \mathrm{kg}$ soil). The results were given for 5 independent measurements, the average value is shown in red. Data provided for 5 samples $(\bullet a, \bullet b, \bullet c, d, \bullet e, \bullet a v$-average for five samples) during 32 weeks of storage at $t=-18^{\circ} \mathrm{C}$. The time dependence of chlorophyll concentration on leaf storage time has also been drawn for control (without contamination).

Figure 3 presents the linear adjustment of $\ln C$ relation to spinach storage time. In frozen spinach, grown on uncontaminated soil, the chlorophyll degradation reaction occurred at a rate constant of $k=0.00679 \pm 0.00027$ week $^{-1}\left(R^{2}=0.958\right)$. On the other hand, in spinach with TC, $k=0.00594 \pm 0.00029$ week $^{-1}\left(R^{2}=0.966\right)$ in the slow degradation range, the process occurred faster in the second range, with constant $k=0.04484 \pm 0.00137$ week $^{-1}\left(R^{2}=0.989\right)$. For cadmium, $k$ constants were higher and amounted to $k=0.00761 \pm 0.00026$ week $^{-1}\left(R^{2}=0.982\right)$ in the first range, and in the second $-k=0.06777 \pm 0.00171$ week $^{-1}\left(R^{2}=0.993\right)$. The value of the constant describing chlorophyll degradation rate in leaves growing without contamination (antibiotics and Cd) in this study corresponds to the values obtained by other authors. Dermesonluoglu et al. (2015) observed a $25 \%$ decrease in chlorophyll content after 36 weeks of storage at $-18{ }^{\circ} \mathrm{C}$. The value of the first-order chlorophyll degradation constant they obtained, converted into the same units, is equal, within the margin of error, to the rate constant $k$ obtained for uncontaminated spinach in the current study.

Some authors suggest that during spinach storage, chlorophyll is decomposed to pheophytin. After three weeks of spinach storage at $8{ }^{\circ} \mathrm{C}$, pheophytin becomes the main chlorophyll degradation product (López-Ayerra et al., 1998). Moharram and Rofael (1993) and Symons (1994) suggest that during storage at low temperatures, chlorophyll is also degraded to pheophytin. Kidmose et al. (2002) indicate that during freezing, 
storage and thermal treatment, chlorophyll is converted or degraded to pheophytin, pheophorbide, pyropheophytin and pyropheophorbide. Niedzielski and Mokrosinska (1990) indicate that before low temperature storage of leaves, their blanching is recommended, as this process causes denaturation of the protein complex, which reduces chlorophyll content loss.
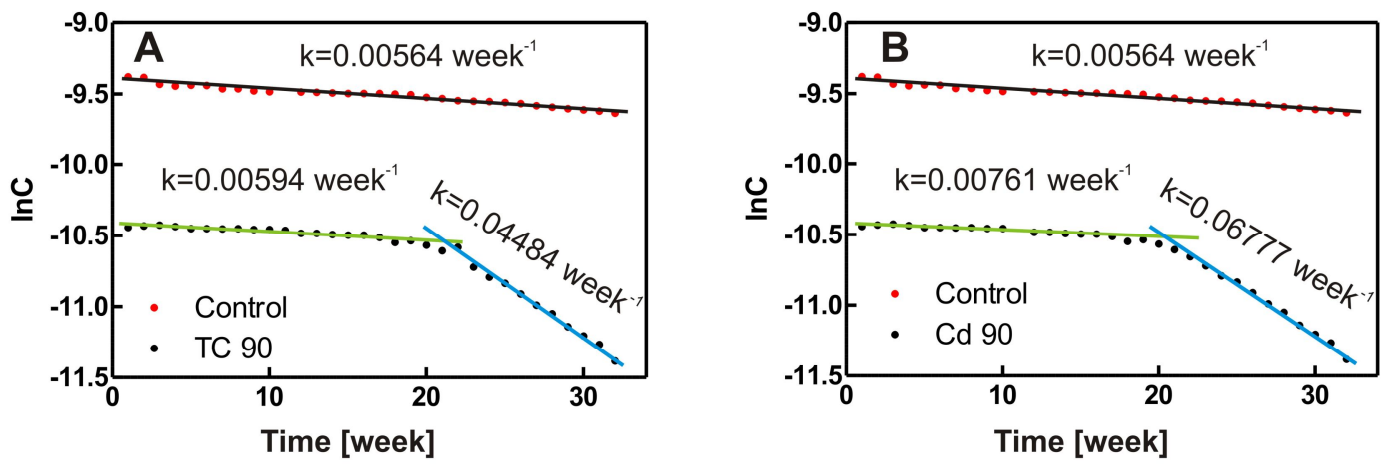

Figure 3. Relation between concentration of chlorophyll extracted from plants growing with antibiotics (A) or cadmium (B) $\left(90 \mathrm{mg} / \mathrm{kg}\right.$ soil) and leaf storage time at $t=-18{ }^{\circ} \mathrm{C}$. Doted points - experimental data, line - obtained from the linear regression based on the experimental data. The following equation was applied: $C=C_{o} e^{-k t}$

In our paper we postulated that the two-range chlorophyll degradation observed in the current study results from the fact that chlorophyll subject to the freezing process is quite quickly degraded in plants growing for 10 days on $\mathrm{TC}$ and $\mathrm{Cd}$ contaminated soil and, afterwards, during the storage of such spinach, degradation occurred slower in the first period, with further strong chlorophyll degradation taking place only after 20 weeks of freezing, as a result of which after 32 weeks, only $19.4 \%$ and $13.6 \%$ chlorophyll was remain in plants contaminated with TC and Cd, respectively. However, for freezing leaves growing without antibiotics or $\mathrm{Cd}$, it was observed that after 32 weeks (in control spinach), 78\% chlorophyll was left. Therefore, $22 \%$ chlorophyll degradation occurred (Fig. 2).

When freezing spinach leaves at $\mathrm{t}=-18{ }^{\circ} \mathrm{C}$, Dermesonluoglu et al. (2015) observed a similar course of degradation as we observed for uncontaminated spinach. On the other hand, King et al. (2001) observed freeze-drying of dehydrated spinach at various temperatures (from $-5{ }^{\circ} \mathrm{C}$ to $-45^{\circ} \mathrm{C}$ ) and found very fast chlorophyll degradation at the beginning, within six weeks, followed by slow degradation. After twelve weeks, chlorophyll degradation reached $45 \%$ at $\mathrm{t}=-20{ }^{\circ} \mathrm{C}$. Even faster chlorophyll degradation in comparison to spinach occurs in turnip greens (Brasica rapa var. rapa L.). During 28-day storage at $-30{ }^{\circ} \mathrm{C}$, chlorophyll a is $40 \%$ degraded and chlorophyll $\mathrm{b}$ is $44 \%$ degraded (Martínez et al., 2013). An interesting result of chlorophyll degradation was obtained by Grzeszczuk et al. (2007) for New Zealand spinach stored at $\mathrm{t}=-25^{\circ} \mathrm{C}$. Changes in chlorophyll content during storage are completely different. Grzeszczuk et al. (2007) observed an initial growth in chlorophyll content in New Zealand spinach in the first three months of storage, and only between month 3 and 6 of storage at about $26^{\circ} \mathrm{C}$, a decrease in chlorophyll content takes place. On the other hand, in dill frozen at $-20^{\circ} \mathrm{C}$, Lisiewska et al. (2004) observed a slow decrease in chlorophyll content up to about week 24, after which chlorophyll degradation was accelerated, similar to 
contaminated spinach leaves examined in the our current research. As it can be concluded from the data quoted above, depending on the plants, chlorophyll degradation during storage at low temperature can have various courses.

Our study also examined the process of chlorophyll degradation in harvest-ready, large, developed spinach leaves. Such spinach (growing for 50 days, of which 10 days with 3, 45 and $90 \mathrm{mg} \mathrm{TC}$ and $\mathrm{Cd}$ per $\mathrm{kg}$ soil) was subject to the freezing process and stored at $\mathrm{t}=-18{ }^{\circ} \mathrm{C}$ for 32 days. The absorption spectra of chlorophyll extracted every week from those leaves are presented in Figure 4. As shown in Figure 4, the decrease in chlorophyll absorption during the storage of harvest-mature leaves contaminated with TC was slower in the first weeks. For three doses of TC and Cd, for $3,45,90 \mathrm{mg} / \mathrm{kg}$ soil, absorbance decreased after 32 weeks to the following values: $A_{3}=0.724$, $\mathrm{A}_{45}=0.637, \mathrm{~A}_{90}=0.500$ for $\mathrm{TC}$, and for $\mathrm{Cd}$ treatment: $\mathrm{A}_{3}=0.714, \mathrm{~A}_{45}=0.583$, $\mathrm{A}_{90}=0.498$ It can be noted that chlorophyll degradation was only slightly lower after Cd application.
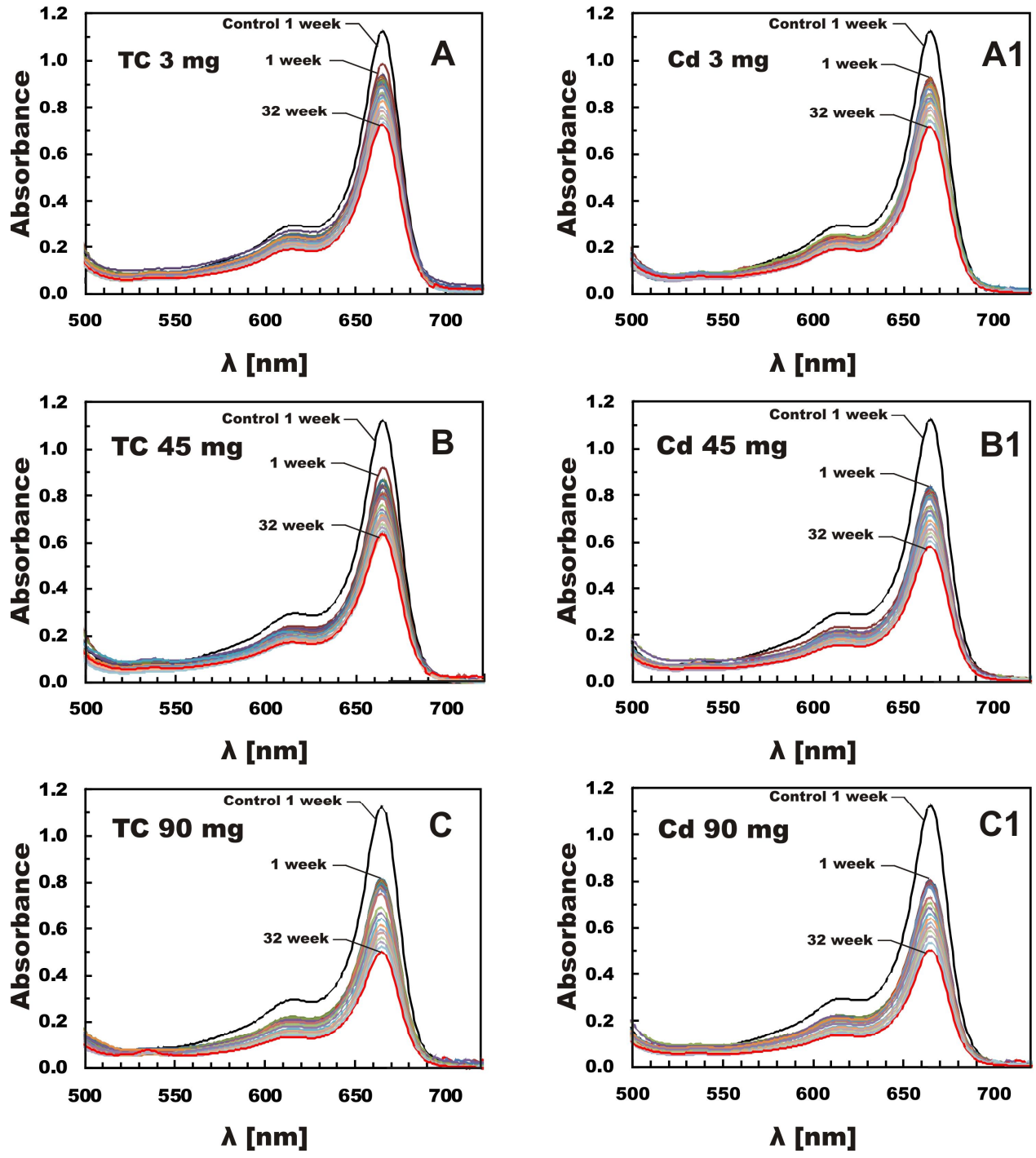

Figure 4. Absorption spectra for chlorophyll extracted from fully developed spinach leaves growing on soil contaminated with tetracycline and cadmium at the dose of: $3 \mathrm{mg} / \mathrm{kg}$ soil (A tetracycline, Al - cadmium), $45 \mathrm{mg} / \mathrm{kg}$ soil (B - tetracycline, B1 - cadmium) and $90 \mathrm{mg} / \mathrm{kg}$ soil (C-tetracycline, $C 1$ - cadmium) 
Figure 5 presents storage time dependence of chlorophyll concentration in subsequent weeks of its storage at $\mathrm{t}=-18^{\circ} \mathrm{C}$ for developed spinach leaves. Statistical data of these changes is shown in Table A2. The percentage content of chlorophyll remaining in spinach after 32 weeks of freezing in relation to the control sample, in which chlorophyll concentration was $\mathrm{C}_{0}=8.42 \times 10^{-5} \mathrm{M}$ (chlorophyll concentration in leaves uncontaminated with $\mathrm{TC}$ and $\mathrm{Cd}$ ), depending on the dose and was amounted for TC: $64.49 \%$ (3 mg) and 56.65\% (45 mg), 44.42\% (90 mg) and for Cd: 63.68\% (3 mg), $51.90 \%(45 \mathrm{mg})$ and $44.54 \%$ (90 $\mathrm{mg})$. The results show that chlorophyll degradation is lower in large, developed leaves, which were subject to the antibiotic and metal treatment only after their development. Undoubtedly, degradation would have taken a completely different course if the plants had grown on the contaminated soil for 50 days. The results clearly indicate that in developed spinach leaves, degradation is also a two-stage process.

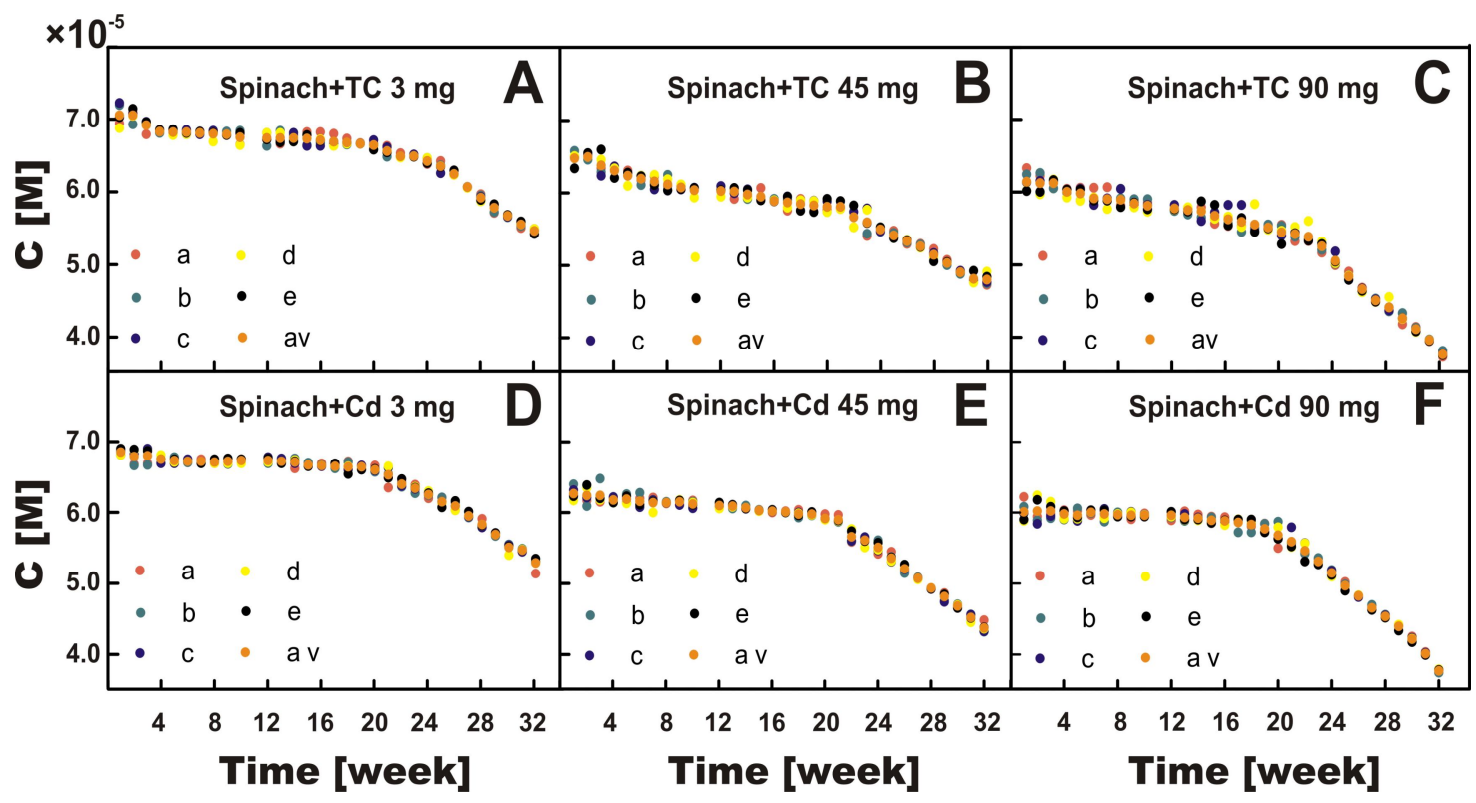

Figure 5. Relation between chlorophyll concentration (C[M]) in large spinach leaves and storage time. Panel A, B, C-plants growing with tetracycline (3, 45 and $90 \mathrm{mg} / \mathrm{kg}$ soil), Panel

$D, E, F$ - with cadmium $(3,45$ and $90 \mathrm{mg} / \mathrm{kg}$ soil). The results were given for 5 independent measurements, the average value is shown in red. Data provided for 5 samples $(\bullet a, \bullet b, \bullet c, d$, $\bullet e,-a v$-average for five samples) during 32 weeks of storage at $t=-18{ }^{\circ} \mathrm{C}$

Table 1 shows degradation rate constants for 50-day spinach contaminated with TC and $\mathrm{Cd}$. As shown in the table, chlorophyll degradation rate constants depend on the TC and $\mathrm{Cd}$ dose, which indicates that $\mathrm{Cd}$ is more toxic in the second range, while degradation occurs faster in plants growing on soil contaminated with $\mathrm{Cd}$. In the first range, degradation rate constants did not differ much, and varied from $k=0.00168 \pm$ 0.00006 week $^{-1}$ to $k=0.00550 \pm 0.00019$ week $^{-1}$ for TC, and from $k=0.00134 \pm$ 0.00014 week ${ }^{1}$ to $k=0.002217 \pm 0.00017$ week $^{-1}$ for $\mathrm{Cd}$. In the second range, the values of $k$ were 10 times higher (Tab.1) and took significantly higher values for Cd. It is also worth emphasizing that degradation rate constants $k$ for $\mathrm{Cd}$ in the first range are lower than for TC. This probably results from the fact that plants have an efficient cadmium resistance mechanism. Metal transporters can play a significant role in 
controlling plant tolerance to $\mathrm{Cd}$ (Rui et al., 2018). It was also demonstrated that plants more readily take up tetracycline from soil than cadmium (Rydzyński et al., 2018).

Table 1. Values of the reaction chlorophyll degradation rate constant $k$ for harvest-ready spinach

\begin{tabular}{|c|c|c|c|c|c|c|}
\hline $\begin{array}{c}\text { Harvesting } \\
\text { maturity of } \\
\text { leaves }\end{array}$ & \multicolumn{3}{|c|}{ I range } & \multicolumn{3}{|c|}{ II range } \\
\hline $\mathrm{mg} / \mathrm{kg}$ soli & $k\left[\right.$ week $\left.^{-1}\right]$ & Storage time & $\mathbf{R}^{2}$ & $k\left[\right.$ week $\left.^{-1}\right]$ & Storage time & $\mathbf{R}^{2}$ \\
\hline TC 3 & $0.00168 \pm 0.00006$ & From 3 to 19 weeks & 0.985 & $0.01551 \pm 0.00117$ & From 20 to 31 weeks & 0.951 \\
\hline TC 45 & $0.00456 \pm 0.00015$ & From 5 to 21 weeks & 0.985 & $0.01811 \pm 0.00054$ & From 21 to 31 weeks & 0.992 \\
\hline TC 90 & $0.00550 \pm 0.00019$ & From 4 to 19 weeks & 0.986 & $0.02945 \pm 0.00151$ & From 19 to 31 weeks & 0.983 \\
\hline $\mathrm{mg} / \mathrm{kg}$ soil & $k\left[\right.$ week $\left.^{-1}\right]$ & & $\mathbf{R}^{2}$ & $k\left[\right.$ week $\left.^{-1}\right]$ & & $\mathbf{R}^{2}$ \\
\hline $\mathrm{Cd} 3$ & $0.00134 \pm 0.00014$ & From 1 to 20 weeks & 0.840 & $0.01855 \pm 0.00079$ & From 21 to 32 weeks & 0.982 \\
\hline $\mathrm{Cd} 45$ & $0.00272 \pm 0.00011$ & From 1 to 21 weeks & 0.971 & $0.02613 \pm 0.00070$ & From 21 to 32 weeks & 0.993 \\
\hline $\mathrm{Cd} 90$ & $0.002217 \pm 0.00020$ & From 1 to 19 weeks & 0.947 & $\begin{array}{l}0.03511 \pm 0.00124 \\
0.03421 \pm 0.00123\end{array}$ & $\begin{array}{l}\text { From } 22 \text { to } 32 \text { weeks } \\
\text { From } 21 \text { to } 32 \text { weeks }\end{array}$ & $\begin{array}{l}0.987 \\
0.987\end{array}$ \\
\hline
\end{tabular}

\section{Conclusion}

The research demonstrated that the degree of chlorophyll degradation depends on the soil contamination degree, the leaf size and the time for which the plant grew on contaminated soil. At the same time, cadmium toxicity is higher despite the plants taking it up in smaller amounts, since chlorophyll degradation is higher in the presence of Cd than TC. To preserve the highest consumption quality of spinach leaves (high chlorophyll content), the leaves intended for freezing should be large and should grow on soil free of any contamination. We recommend storing spinach leaves at $-18{ }^{\circ} \mathrm{C}$ for not longer than 20 weeks. In addition to the analysis of chlorophyll quality, the studies of stored leaves from spinach grown on contaminated soils will be carried out in the immediate future to consider biologically active substances such as vitamins, carotenes, xanthophylls that have a significant impact on the biological value of the vegetable raw material.

\section{REFERENCES}

[1] Azeez, J. O., Adekunle, I. O., Atiku, O. O., Akande, K. B., Jamiu-Azeez, S. O. (2009): Effect of nine years of animal waste deposition on profile distribution of heavy metals in Abeokuta, south-western Nigeria and its implication for environmental quality. - Waste Management 29(9): 2582-2586.

[2] Bartha, B., Huber, C., Harpaintner, R., Schröder, P. (2010): Effects of acetaminophen in Brassica juncea L. Czern.: investigation of uptake, translocation, detoxification, and the induced defense pathways. - Environmental Science and Pollution Research 17(9): 15531562.

[3] D’Abrosca, B., Fiorentino, A., Izzo, A., Cefarelli, G., Pascarella, M. T., Uzzo, P., Monaco, P. (2008): Phytotoxicity evaluation of five pharmaceutical pollutants detected in surface water on germination and growth of cultivated and spontaneous plants. - Journal of Environmental Science and Health Part A 43(3): 285-294. 
[4] Dermesonluoglu, E., Katsaros, G., Tsevdou, M., Giannakourou, M., Taoukis, P. (2015): Kinetic study of quality indices and shelf life modelling of frozen spinach under dynamic conditions of the cold chain. - Journal of Food Engineering 148: 13-23.

[5] Gore, R. D., Palaskar, S. J., Bartake, A. R. (2017): Wheatgrass: green blood can help to fight cancer. - Journal of Clinical and Diagnostic Research 11(6): ZC40-ZC42.

[6] Grzeszczuk, M., Jadczak, D., Podsiadło, C. (2007): The effect of blanching, freezing and freeze-storage on changes of some chemical compounds content in New Zealand spinach. - Vegetable Crops Research Bulletin 2(66): 95-103.

[7] IUNG (2017): Monitoring Chemizmu Gleb Ornych Polski (in Polish). https://www.gios.gov.pl/chemizm gleb/index.php?mod=wyniki\&cz=G.

[8] Jaworska, G. (2005): Nitrates, nitrites, and oxalates in products of spinach and New Zealand spinach: effect of technological measures and storage time on the level of nitrates, nitrites, and oxalates in frozen and canned products of spinach and New Zealand spinach. - Food Chemistry 93: 395-401.

[9] Jaworska, G., Kmiecik, W. (2000): Comparison of the nutritive value of frozen spinach and New Zealand spinach. - Polish Journal of Food and Nutrition Sciences 50(4): 79-84.

[10] Kidmose, U., Edelenbos, M., Nørbæk, R., Christensen, L. P. (2002): Colour Stability in Vegetables. - In: MacDougall, D. B. (ed.) Colour in Food: Improving. CRC Press LLC, Boca Raton, pp. 179-232.

[11] Kim, S. C., Carlson, K. (2007): Temporal and spatial trends in the occurrence of human and veterinary antibiotics in aqueous and river sediment matrices. - Environmental Science \& Technology 41(1): 50-57.

[12] King, V. A. E., Liu, C. F., Liu, Y. J. (2001): Chlorophyll stability in spinach dehydrated by freeze-drying and controlled low-temperature vacuum dehydration. - Food Research International 34(2-3): 167-175.

[13] Koca, N., Karadeniz, F., Burdurlu, H. S. (2007): Effect of pH on chlorophyll degradation and colour loss in blanched green peas. - Food Chemistry 100: 609-615.

[14] Kong, W. D., Zhu, Y. G., Liang, Y. C., Zhang, J., Smith, F. A., Yang, M. (2007): Uptake of oxytetracycline and its phytotoxicity to alfalfa (Medicago sativa L.). - Environmental Pollution 147(1): 187-193.

[15] Kou, L., Luo, Y., Park, E., Turner, E. R., Barczak, A., Jurick, W. M. (2014): Temperature abuse timing affects the rate of quality deterioration of commercially packaged ready-toeat baby spinach. Part I: sensory analysis and selected quality attributes. - Postharvest Biology and Technology 91: 96-103.

[16] Kummerova, M., Bartak, M., Dubova, J., Triska, J., Zubrova, E., Zezulka, S. (2006): Inhibitory effect of fluoranthene on photosynthetic processes in lichens detected by chlorophyll fluorescence. - Ecotoxicology 15: 121-131.

[17] Küpper, H., Lombi, E., Zhao, F. J., Wieshammer, G., McGrath, S. P. (1996): Cellular compartmentation of nickel in the hyperaccumulators Alyssum lesbiacum, Alyssum bertolonii and Thlaspi goesingense. - Journal of Experimental Botany 52(365): 22912300.

[18] Küpper, H., Lombi, E., Zhao, F. J., McGrath, S. P. (2000): Cellular compartmentation of cadmium and zinc in relation to other elements in the hyperaccumulator Arabidopsis halleri. - Planta 212: 75-84.

[19] Küpper, H., Küpper, F., Spiller, M. (2001): Environmental relevance of heavy metal substituted chlorophylls using the example of water plants. - Journal of Experimental Botany 47: 259-266.

[20] Li, Z. J., Xie, X. Y., Zhang, S. Q., Liang, Y. C. (2011): Negative effects of oxytetracycline on wheat (Triticum aestivum L.) growth, root activity, photosynthesis, and chlorophyll contents. - Agricultural Sciences in China 10(10): 1545-1553.

[21] Lisiewska, Z., Kmiecik, W., Słupski, J. (2004): Contents of chlorophylls and carotenoids in frozen dill: effect of usable part and pre-treatment on the content of chlorophylls and 
carotenoids in frozen dill (Anethum graveolens L.), depending on the time and temperature of storage. - Food Chemistry 84: 511-518.

[22] Lisiewska, Z., Gebczynski, P., Bernas, E., Kmiecik, W. (2009): Retention of mineral constituents in frozen leafy vegetables prepared for consumption. - Journal of Food Composition and Analysis 22: 218-223.

[23] Liu, L., Liu, Y. H., Liu, C. X., Wang, Z., Dong, J., Zhu, G. F., Huang, X. (2013): Potential effect and accumulation of veterinary antibiotics in Phragmites australis under hydroponic conditions. - Ecological Engineering 53: 138-143.

[24] López-Ayerra, B., Murcia, A. M., Garcia-Carmona, F. (1998): Lipid peroxidation and chlorophyll levels in spinach during refrigerated storage and after industrial processing. Food Chemistry 61: 113-118.

[25] López-Millán, A. F., Morales, F., Gogorcena, Y., Abadía, A., Abadía, J. (2009): Metabolic responses in iron deficient tomato plants. - Journal of Plant Physiology 166(4): 375-384.

[26] Martínez, S., Pérez, N., Carballo, J., Franco, I. (2013): Effect of blanching methods and frozen storage on some quality parameters of turnip greens ("grelos"). - LWT - Food Science and Technology 51(1): 383-392.

[27] Mishra, S., Srivastava, S., Tripathi, R. D., Govidarajan, R., Kuriakose, S. V., Prasad, M. N. V. (2006): Phytochelatin synthesis and response of antioxidants during cadmium stress in Bacopa monnieri L. - Journal of Plant Physiology and Biochemistry 44: 25-37.

[28] Moharram, Y. G., Rofael, S. D. (1993): Shelf Life of Frozen Vegetables. - In: Charalambous, G. (ed.) Shelf Life Studies of Foods and Beverages. Elsevier Science Publishers BV, Amsterdam.

[29] Nicholson, F. A., Smith, S. R., Alloway, B. J., Carlton-Smith, C., Chambers, B. J. (2003): An inventory of heavy metals inputs to agricultural soils in England and Wales. - Science of the Total Environment 311(1-3): 205-219.

[30] Niedzielski, Z., Mokrosińska, K. (1990): Wpływ mrożenia gazami skroplonymi na jakość przechowywanej kapusty brukselskiej. - Zeszyty Nauk Politechniki Łódzkiej, seria Technol Chem Spoż 47: 119-125 (English summary).

[31] Pan, M., Chu, L. M. (2017): Fate of antibiotics in soil and their uptake by edible crops. Science of the Total Environment 599-600: 500-512.

[32] Patar, A. K., Bhan, S., Syiem, D. (2016): Effect of chlorophyllin, an semi-synthetic chlorophyll molecule on hyperglycemia and hyperlipidemia in streptozotocin induced diabetic mice. - International Journal of Pharmacy and Pharmaceutical Sciences 8: 293296.

[33] Pukszta, T., Palich, P. (2007): The effect of freezing conditions of strawberry storage on the level of thawing drip loss. - Acta Agrophysica 9: 203-208.

[34] Rui, H., Zhang, X., Shinwari, K. I., Zheng, L., Shen, Z. (2018): Comparative transcriptomic analysis of two Vicia sativa $\mathrm{L}$. varieties with contrasting responses to cadmium stress reveals the important role of metal transporters in cadmium tolerance. Plant Soil 423(1-2): 41-255.

[35] Rydzyński, D., Piotrowicz-Cieślak, A. I., Grajek, H., Michalczyk, D. J. (2017): Instability of chlorophyll in yellow lupin seedlings grown in soil contaminated with ciprofloxacin and tetracycline. - Chemosphere 184: 62-73.

[36] Rydzyński, D., Piotrowicz-Cieślak, A. I., Grajek, H., Michalczyk, D. J. (2018): Different ways of chlorophyll degradation by tetracycline and cadmium in spinach (Spinacia oleracea L.) leaves. - International Journal of Environmental Science and Technology DOI: $10.1007 / \mathrm{s} 13762-018-2142-8$.

[37] Sánchez, C., Baranda, A. B., Martínez de Marañón, I. (2014): The effect of high pressure and high temperature processing on carotenoids and chlorophylls content in some vegetables. - Food Chemistry 163: 37-45.

[38] Seely, G. R., Jensen, R. G. (1965): Effect of solvent on the spectra of chlorophyll. Spectrochimica Acta 21(10): 1835-1845. 
[39] Smeets, K., Cuypers, A., Lambrechts, A., Semane, B., Hoet, P., Laerve, A. V., Vangronsveld, J. (2005): Induction of oxidative stress and antioxidative mechanisms in Phaseolus vulgaris after Cd application. - Journal of Plant Physiology and Biochemistry 43: 437-444.

[40] Steet, J. A. Tong, C. H. (1996): Degradation of green color and chlorophylls in peas by colorimetry and HPLC. - Journal of Food Science 61(5): 924-928.

[41] Symons, H. (1994): Frozen Foods. - In: Man, C. M. D., Jones, A. A. (eds.) Shelf Life Evaluation of Foods. Blackie Academic Professional. London.

[42] Van Buggenhout, S., Lille, M., Messagie, I., Van Loey, A., Autio, K., Hendrickx, M. (2006): Impact of pretreatment and freezing conditions on the microstructure of frozen carrots: qualification and relation to texture loss. - European Food Research and Technology 222: 43-553.

[43] Xie, J., Zhu, J., Lin, Y. (2013): Effect of vacuum pre-cooling on quality changes of spinach during cold storage. - Advanced Materials Research. 641-642(1): 886-889.

[44] Zhang, H., Zhou, Y., Huang, Y., Wu, L., Liu, X., Luo, Y. (2016): Residues and risks of veterinary antibiotics in protected vegetable soils following application of different manures. - Chemosphere 152: 229-237.

\section{APPENDIX}

Table A1. Statistical analysis of chlorophyll content in small leaves of plants grown in soil contaminated with tetracycline or cadmium (means $\pm S D$; different lowercase letters denote significantly different results across storage periods, different capital letters denote significant differences across contaminant doses; NIR $\leq 0.01$ )

\begin{tabular}{|c|c|c|c|}
\hline \multirow[t]{2}{*}{ t (week) } & $\begin{array}{c}\text { Control } \\
\mathrm{C}(\mathrm{M}) \times 10^{-5}\end{array}$ & Tetracycline C $(\mathrm{M}) \times 10^{-5}$ & Cadmium C (M) $\times 10^{-5}$ \\
\hline & 0 mg & $90 \mathrm{mg}$ & $90 \mathrm{mg}$ \\
\hline 1 & $8.45 \pm 0.14^{\mathrm{aA}}$ & $3.05 \pm 0.03^{\mathrm{aB}}$ & $2.92 \pm 0.02^{\mathrm{aB}}$ \\
\hline 2 & $8.42 \pm 0.11^{\mathrm{aA}}$ & $3.10 \pm 0.11^{\mathrm{aB}}$ & $2.95 \pm 0.07^{\mathrm{aB}}$ \\
\hline 3 & $8.02 \pm 0.10^{\mathrm{aA}}$ & $3.05 \pm 0.04^{\mathrm{aB}}$ & $2.97 \pm 0.05^{\mathrm{aB}}$ \\
\hline 4 & $7.93 \pm 0.07^{\mathrm{aA}}$ & $2.96 \pm 0.05^{\mathrm{aB}}$ & $2.94 \pm 0.06^{\mathrm{aB}}$ \\
\hline 5 & $7.97 \pm 0.10^{\mathrm{aA}}$ & $2.95 \pm 0.02^{\mathrm{aB}}$ & $2.90 \pm 0.06^{\mathrm{aB}}$ \\
\hline 6 & $7.96 \pm 0.05^{\mathrm{aA}}$ & $2.96 \pm 0.01^{\mathrm{aB}}$ & $2.90 \pm 0.03^{\mathrm{aB}}$ \\
\hline 7 & $7.78 \pm 0.10^{\mathrm{bA}}$ & $2.95 \pm 0.02^{\mathrm{aB}}$ & $2.89 \pm 0.04^{\mathrm{aB}}$ \\
\hline 8 & $7.78 \pm 0.09^{\mathrm{bA}}$ & $2.94 \pm 0.02^{\mathrm{aB}}$ & $2.90 \pm 0.04^{\mathrm{aB}}$ \\
\hline 9 & $7.66 \pm 0.09^{\mathrm{bA}}$ & $2.94 \pm 0.02^{\mathrm{aB}}$ & $2.88 \pm 0.02^{\mathrm{aB}}$ \\
\hline 10 & $7.62 \pm 0.12^{\mathrm{bA}}$ & $2.89 \pm 0.07^{\mathrm{aB}}$ & $2.88 \pm 0.03^{\mathrm{aB}}$ \\
\hline 11 & $7.62 \pm 0.12^{\mathrm{bA}}$ & $2.86 \pm 0.05^{\mathrm{aB}}$ & $2.88 \pm 0.03^{\mathrm{aB}}$ \\
\hline 12 & $7.61 \pm 0.04^{\mathrm{bA}}$ & $2.85 \pm 0.02^{\mathrm{aB}}$ & $2.80 \pm 0.02^{\mathrm{aB}}$ \\
\hline 13 & $7.58 \pm 0.08^{\mathrm{bA}}$ & $2.84 \pm 0.00^{\mathrm{aB}}$ & $2.80 \pm 0.03^{\mathrm{aB}}$ \\
\hline 14 & $7.55 \pm 0.08^{\mathrm{bA}}$ & $2.79 \pm 0.05^{\mathrm{aB}}$ & $2.78 \pm 0.03^{\mathrm{aB}}$ \\
\hline 15 & $7.53 \pm 0.12^{\mathrm{bA}}$ & $2.80 \pm 0.05^{\mathrm{aB}}$ & $2.77 \pm 0.03^{\mathrm{aB}}$ \\
\hline 16 & $7.53 \pm 0.07^{\mathrm{bA}}$ & $2.79 \pm 0.01^{\mathrm{aB}}$ & $2.77 \pm 0.02^{\mathrm{aB}}$ \\
\hline 17 & $7.53 \pm 0.11^{\mathrm{bA}}$ & $2.79 \pm 0.03^{\mathrm{aB}}$ & $2.72 \pm 0.03^{\mathrm{aB}}$ \\
\hline 18 & $7.49 \pm 0.06^{\mathrm{cA}}$ & $2.79 \pm 0.02^{\mathrm{aB}}$ & $2.63 \pm 0.07^{\mathrm{aB}}$ \\
\hline 19 & $7.46 \pm 0.10^{\mathrm{cA}}$ & $2.77 \pm 0.02^{\mathrm{aB}}$ & $2.66 \pm 0.01^{\mathrm{aB}}$ \\
\hline 20 & $7.32 \pm 0.08^{\mathrm{cA}}$ & $2.72 \pm 0.01^{\mathrm{aB}}$ & $2.58 \pm 0.05^{\mathrm{aB}}$ \\
\hline 21 & $7.27 \pm 0.06^{\mathrm{cA}}$ & $2.69 \pm 0.02^{\mathrm{bB}}$ & $2.48 \pm 0.06^{\mathrm{bB}}$ \\
\hline
\end{tabular}




\begin{tabular}{l|l|l|l}
22 & $7.16 \pm 0.09^{\mathrm{CA}}$ & $2.54 \pm 0.03^{\mathrm{BB}}$ & $2.54 \pm 0.04^{\mathrm{bB}}$ \\
23 & $7.13 \pm 0.09^{\mathrm{cA}}$ & $2.46 \pm 0.01^{\mathrm{CB}}$ & $2.21 \pm 0.09^{\mathrm{bB}}$ \\
24 & $7.11 \pm 0.16^{\mathrm{CA}}$ & $2.41 \pm 0.01^{\mathrm{dB}}$ & $2.06 \pm 0.02^{\mathrm{CC}}$ \\
25 & $7.07 \pm 0.04^{\mathrm{CA}}$ & $2.31 \pm 0.03^{\mathrm{eB}}$ & $1.97 \pm 0.04^{\mathrm{CC}}$ \\
26 & $7.01 \pm 0.01^{\mathrm{dA}}$ & $2.20 \pm 0.04^{\mathrm{eB}}$ & $1.83 \pm 0.02^{\mathrm{cC}}$ \\
27 & $6.91 \pm 0.01^{\mathrm{dA}}$ & $2.05 \pm 0.04^{\mathrm{eB}}$ & $1.69 \pm 0.02^{\mathrm{dC}}$ \\
28 & $6.84 \pm 0.06^{\mathrm{dA}}$ & $1.95 \pm 0.01^{\mathrm{eB}}$ & $1.59 \pm 0.09^{\mathrm{dC}}$ \\
29 & $6.76 \pm 0.01^{\mathrm{dA}}$ & $1.87 \pm 0.05^{\mathrm{bB}}$ & $1.45 \pm 0.02^{\mathrm{dC}}$ \\
30 & $6.71 \pm 0.06^{\mathrm{dA}}$ & $1.79 \pm 0.06^{\mathrm{bB}}$ & $1.36 \pm 0.06^{\mathrm{dC}}$ \\
31 & $6.65 \pm 0.01^{\mathrm{dA}}$ & $1.70 \pm 0.03^{\mathrm{bB}}$ & $1.28 \pm 0.07^{\mathrm{dC}}$ \\
32 & $6.56 \pm 0.08^{\mathrm{eA}}$ & $1.63 \pm 0.04^{\mathrm{bB}}$ & $1.14 \pm 0.06^{\mathrm{dC}}$ \\
\hline
\end{tabular}

Table A2. Statistical analysis of chlorophyll content in mature leaves of plants grown in soil contaminated with tetracycline or cadmium (means $\pm S D$; different lowercase letters denote significantly different results across storage periods, different capital letters denote significant differences across contaminant doses; NIR $\leq 0.01$ )

\begin{tabular}{|c|c|c|c|c|c|c|}
\hline \multirow{2}{*}{ t (week) } & \multicolumn{3}{|c|}{ Tetracycline C $(\mathrm{M}) \times 10^{-5}$} & \multicolumn{3}{|c|}{ Cadmium C (M) $\times 10^{-5}$} \\
\hline & $3 \mathrm{mg}$ & $45 \mathrm{mg}$ & $90 \mathrm{mg}$ & $3 \mathrm{mg}$ & $45 \mathrm{mg}$ & $90 \mathrm{mg}$ \\
\hline 1 & $7.04 \pm 0.16^{\mathrm{aA}}$ & $6.45 \pm 0.08^{\mathrm{aB}}$ & $6.12 \pm 0.13^{\mathrm{aB}}$ & $6.92 \pm 0.04^{\mathrm{aA}}$ & $6.26 \pm 0.09^{\mathrm{aB}}$ & $6.00 \pm 0.14^{\mathrm{aB}}$ \\
\hline 2 & $7.04 \pm 0.08^{\mathrm{aA}}$ & $6.47 \pm 0.03^{\mathrm{aB}}$ & $6.10 \pm 0.13^{\mathrm{aB}}$ & $6.86 \pm 0.11^{\mathrm{aA}}$ & $6.23 \pm 0.12^{\mathrm{aB}}$ & $6.01 \pm 0.18^{\mathrm{aB}}$ \\
\hline 3 & $6.90 \pm 0.07^{\mathrm{aA}}$ & $6.35 \pm 0.15^{\mathrm{aB}}$ & $6.10 \pm 0.06^{\mathrm{aB}}$ & $6.87 \pm 0.11^{\mathrm{aA}}$ & $6.23 \pm 0.13^{\mathrm{aB}}$ & $6.01 \pm 0.10^{\mathrm{aB}}$ \\
\hline 4 & $6.81 \pm 0.02^{\mathrm{aA}}$ & $6.28 \pm 0.06^{\mathrm{aB}}$ & $5.98 \pm 0.05^{\mathrm{aB}}$ & $6.82 \pm 0.04^{\mathrm{aA}}$ & $6.17 \pm 0.04^{\mathrm{aB}}$ & $5.97 \pm 0.06^{\mathrm{aB}}$ \\
\hline 5 & $6.80 \pm 0.03^{\mathrm{aA}}$ & $6.21 \pm 0.08^{\mathrm{aB}}$ & $5.96 \pm 0.09^{\mathrm{aB}}$ & $6.80 \pm 0.04^{\mathrm{aA}}$ & $6.18 \pm 0.06^{\mathrm{aB}}$ & $5.95 \pm 0.08^{\mathrm{aB}}$ \\
\hline 6 & $6.70 \pm 0.03^{\mathrm{aA}}$ & $6.17 \pm 0.06^{\mathrm{aB}}$ & $5.89 \pm 0.09^{\mathrm{aB}}$ & $6.79 \pm 0.02^{\mathrm{aA}}$ & $6.15 \pm 0.08^{\mathrm{aB}}$ & $5.99 \pm 0.03^{\mathrm{aB}}$ \\
\hline 7 & $6.79 \pm 0.02^{\mathrm{aA}}$ & $6.13 \pm 0.08^{\mathrm{aB}}$ & $5.88 \pm 0.11^{\mathrm{aB}}$ & $6.79 \pm 0.02^{\mathrm{aA}}$ & $6.13 \pm 0.08^{\mathrm{aB}}$ & $5.97 \pm 0.09^{\mathrm{aB}}$ \\
\hline 8 & $6.77 \pm 0.06^{\mathrm{aA}}$ & $6.09 \pm 0.09^{\mathrm{aB}}$ & $5.87 \pm 0.10^{\mathrm{aB}}$ & $6.78 \pm 0.03^{\mathrm{aA}}$ & $6.13 \pm 0.01^{\mathrm{aB}}$ & $5.96 \pm 0.02^{\mathrm{aB}}$ \\
\hline 9 & $6.77 \pm 0.02^{\mathrm{aA}}$ & $6.05 \pm 0.03^{\mathrm{aB}}$ & $5.82 \pm 0.05^{\mathrm{aB}}$ & $6.79 \pm 0.04^{\mathrm{aA}}$ & $6.14 \pm 0.04^{\mathrm{aB}}$ & $5.95 \pm 0.04^{\mathrm{aB}}$ \\
\hline 10 & $6.73 \pm 0.10^{\mathrm{aA}}$ & $6.01 \pm 0.06^{\mathrm{bB}}$ & $5.79 \pm 0.07^{\mathrm{aB}}$ & $6.80 \pm 0.03^{\mathrm{aA}}$ & $6.11 \pm 0.04^{\mathrm{aB}}$ & $5.95 \pm 0.02^{\mathrm{aB}}$ \\
\hline 11 & $6.73 \pm 0.11^{\mathrm{aA}}$ & $6.01 \pm 0.06^{\mathrm{bB}}$ & $5.78 \pm 0.07^{\mathrm{aB}}$ & $6.80 \pm 0.03^{\mathrm{aA}}$ & $6.10 \pm 0.04^{\mathrm{aB}}$ & $5.95 \pm 0.01^{\mathrm{aB}}$ \\
\hline 12 & $6.72 \pm 0.07^{\mathrm{aA}}$ & $6.00 \pm 0.05^{\mathrm{bB}}$ & $5.75 \pm 0.03^{\mathrm{aB}}$ & $6.80 \pm 0.04^{\mathrm{aA}}$ & $6.09 \pm 0.03^{\mathrm{aB}}$ & $5.95 \pm 0.05^{\mathrm{aB}}$ \\
\hline 13 & $6.72 \pm 0.08^{\mathrm{aA}}$ & $5.99 \pm 0.07^{\mathrm{bB}}$ & $5.73 \pm 0.04^{\mathrm{aB}}$ & $6.79 \pm 0.03^{\mathrm{aA}}$ & $6.08 \pm 0.02^{\mathrm{aB}}$ & $5.92 \pm 0.06^{\mathrm{aB}}$ \\
\hline 14 & $6.72 \pm 0.06^{\mathrm{aA}}$ & $5.95 \pm 0.07^{\mathrm{cB}}$ & $5.71 \pm 0.11^{\mathrm{aB}}$ & $6.78 \pm 0.05^{\mathrm{aA}}$ & $6.06 \pm 0.02^{\mathrm{aB}}$ & $5.91 \pm 0.03^{\mathrm{aB}}$ \\
\hline 15 & $6.71 \pm 0.09^{\mathrm{aA}}$ & $5.92 \pm 0.07^{\mathrm{cB}}$ & $5.65 \pm 0.10^{\mathrm{aB}}$ & $6.74 \pm 0.02^{\mathrm{aA}}$ & $6.02 \pm 0.01^{\mathrm{aB}}$ & $5.88 \pm 0.04^{\mathrm{aB}}$ \\
\hline 16 & $6.60 \pm 0.07^{\mathrm{aA}}$ & $5.86 \pm 0.01^{\mathrm{cB}}$ & $5.60 \pm 0.14^{\mathrm{bB}}$ & $6.73 \pm 0.02^{\mathrm{aA}}$ & $6.01 \pm 0.01^{\mathrm{aB}}$ & $5.87 \pm 0.04^{\mathrm{aB}}$ \\
\hline 17 & $6.67 \pm 0.07^{\mathrm{aA}}$ & $5.84 \pm 0.09^{\mathrm{cB}}$ & $5.57 \pm 0.15^{\mathrm{bB}}$ & $6.72 \pm 0.03^{\mathrm{aA}}$ & $6.00 \pm 0.01^{\mathrm{aB}}$ & $5.85 \pm 0.08^{\mathrm{aB}}$ \\
\hline 18 & $6.66 \pm 0.03^{\mathrm{aA}}$ & $5.82 \pm 0.09^{\mathrm{cB}}$ & $5.53 \pm 0.16^{\mathrm{bB}}$ & $6.71 \pm 0.08^{\mathrm{aA}}$ & $5.97 \pm 0.04^{\mathrm{aB}}$ & $5.82 \pm 0.07^{\mathrm{aB}}$ \\
\hline 19 & $6.64 \pm 0.01^{\mathrm{aA}}$ & $5.80 \pm 0.09^{\mathrm{cB}}$ & $5.49 \pm 0.03^{\mathrm{cB}}$ & $6.71 \pm 0.03^{\mathrm{aA}}$ & $5.97 \pm 0.02^{\mathrm{aB}}$ & $5.76 \pm 0.06^{\mathrm{aB}}$ \\
\hline 20 & $6.62 \pm 0.05^{\mathrm{aA}}$ & $5.78 \pm 0.09^{\mathrm{cB}}$ & $5.42 \pm 0.11^{\mathrm{cB}}$ & $6.67 \pm 0.03^{\mathrm{aA}}$ & $5.91 \pm 0.03^{\mathrm{aB}}$ & $5.67 \pm 0.15^{\mathrm{aB}}$ \\
\hline 21 & $6.54 \pm 0.06^{\mathrm{aA}}$ & $5.78 \pm 0.05^{\mathrm{cB}}$ & $5.40 \pm 0.08^{\mathrm{cB}}$ & $6.60 \pm 0.12^{\mathrm{aA}}$ & $5.89 \pm 0.04^{\mathrm{aB}}$ & $5.58 \pm 0.11^{\mathrm{aB}}$ \\
\hline 22 & $6.47 \pm 0.02^{\mathrm{bA}}$ & $5.64 \pm 0.14^{\mathrm{cB}}$ & $5.36 \pm 0.14^{\mathrm{dB}}$ & $6.47 \pm 0.04^{\mathrm{bA}}$ & $5.65 \pm 0.09^{\mathrm{bB}}$ & $5.45 \pm 0.11^{\mathrm{bB}}$ \\
\hline 23 & $6.47 \pm 0.01^{\mathrm{bA}}$ & $5.57 \pm 0.18^{\mathrm{cB}}$ & $5.23 \pm 0.07^{\mathrm{dB}}$ & $6.41 \pm 0.04^{\mathrm{bA}}$ & $5.60 \pm 0.06^{\mathrm{bB}}$ & $5.30 \pm 0.04^{\mathrm{bB}}$ \\
\hline 24 & $6.39 \pm 0.04^{\mathrm{bA}}$ & $5.47 \pm 0.03^{\mathrm{cB}}$ & $5.03 \pm 0.08^{\mathrm{eC}}$ & $6.32 \pm 0.04^{\mathrm{bA}}$ & $5.50 \pm 0.08^{\mathrm{cB}}$ & $5.14 \pm 0.04^{\mathrm{cB}}$ \\
\hline 25 & $6.32 \pm 0.06^{\mathrm{aA}}$ & $5.39 \pm 0.04^{\mathrm{dB}}$ & $4.82 \pm 0.04^{\mathrm{eC}}$ & $6.22 \pm 0.06^{\mathrm{bA}}$ & $5.35 \pm 0.06^{\mathrm{cB}}$ & $4.96 \pm 0.05^{\mathrm{cB}}$ \\
\hline 26 & $6.23 \pm 0.03^{\mathrm{bA}}$ & $5.31 \pm 0.03^{\mathrm{dB}}$ & $4.64 \pm 0.02^{\mathrm{eC}}$ & $6.16 \pm 0.06^{\mathrm{bA}}$ & $5.20 \pm 0.05^{\mathrm{dB}}$ & $4.82 \pm 0.02^{\mathrm{cB}}$ \\
\hline 27 & $6.05 \pm 0.01^{\mathrm{bA}}$ & $5.24 \pm 0.02^{\mathrm{dB}}$ & $4.49 \pm 0.02^{\mathrm{fC}}$ & $6.02 \pm 0.03^{\mathrm{cA}}$ & $5.07 \pm 0.01^{\mathrm{dB}}$ & $4.65 \pm 0.03^{\mathrm{cB}}$ \\
\hline
\end{tabular}




$$
-6835-
$$

\begin{tabular}{l|l|l|l|l|l|l}
28 & $5.89 \pm 0.04^{\mathrm{bA}}$ & $5.12 \pm 0.06^{\mathrm{dB}}$ & $4.39 \pm 0.08^{\mathrm{aC}}$ & $5.90 \pm 0.05^{\mathrm{cA}}$ & $4.93 \pm 0.01^{\mathrm{dB}}$ & $4.53 \pm 0.02^{\mathrm{cC}}$ \\
29 & $5.75 \pm 0.06^{\mathrm{CA}}$ & $5.01 \pm 0.03^{\mathrm{eB}}$ & $4.24 \pm 0.05^{\mathrm{fC}}$ & $5.76 \pm 0.02^{\mathrm{cA}}$ & $4.81 \pm 0.06^{\mathrm{dB}}$ & $4.39 \pm 0.04^{\mathrm{cC}}$ \\
30 & $5.64 \pm 0.01^{\mathrm{bA}}$ & $4.88 \pm 0.02^{\mathrm{eB}}$ & $4.09 \pm 0.03^{\mathrm{fC}}$ & $5.58 \pm 0.06^{\mathrm{dA}}$ & $4.68 \pm 0.02^{\mathrm{eB}}$ & $4.21 \pm 0.03^{\mathrm{cC}}$ \\
31 & $5.52 \pm 0.03^{\mathrm{bA}}$ & $4.79 \pm 0.06^{\mathrm{eB}}$ & $3.94 \pm 0.01^{\mathrm{gC}}$ & $5.54 \pm 0.02^{\mathrm{dA}}$ & $4.52 \pm 0.05^{\mathrm{eB}}$ & $4.01 \pm 0.02^{\mathrm{dC}}$ \\
32 & $5.43 \pm 0.03^{\mathrm{cA}}$ & $4.78 \pm 0.07^{\mathrm{eB}}$ & $3.74 \pm 0.03^{\mathrm{gC}}$ & $5.36 \pm 0.09^{\mathrm{eA}}$ & $4.37 \pm 0.06^{6 \mathrm{eB}}$ & $3.77 \pm 0.02^{\mathrm{eC}}$ \\
\hline
\end{tabular}

